\title{
CHARACTERIZATION OF SOME REPRESENTATIVE SOILS FROM THE GANGES FLOODPLAIN OF BANGLADESH
}

\author{
M.K. Hasan, A.S.M. MohiUddin AND M.J. UdDin* \\ Department of Soil, Water and Environment, University of Dhaka, Dhaka-1000, Bangladesh
}

Key words: Characterization, Hydromorphic soils, The Ganges Floodplain

The Ganges floodplain comprises the vast stretches of the fabulously fertile active floodplain of the Ganges river and the adjoining meander floodplain and its soils are the major agricultural soils of Bangladesh that work as their lifeline. This physiographic unit is almost triangular in shape and bounded by the Ganges tidal floodplain on the south. On its southern end it traps the Gopalganj-Khulna Beels ${ }^{(1)}$. The Gangetic alluvium generally is calcareous and rich in weatherable minerals but the clay minerals include expanding lattice 2:1 Montmorillonite which gives the soils extreme shrink - swell properties. It is the largest physiographic unit in Bangladesh with variety of nature ${ }^{(1,2)}$.

The present study was undertaken in examining the soil properties regarding their morphological, physical, chemical characteristics as well as their use potentials.

A total of 22 soil samples were collected on natural horizon basis from four soil profiles for laboratory analyses representing the study sites. The soils were morphologically described in the field following the method of Soil Survey Manual(3). The soil samples were processed and analyzed in the laboratory. The particle size analysis of soils was carried out by combination of sieving and hydrometer methods as described by Day ${ }^{(4)}$. Textural classes were determined by Marshell's triangular coordinate curve as devised by USDA ${ }^{(5)}$. Hygroscopic moisture content of soils was determined by drying the air-dried soils in an oven at $105-110^{\circ} \mathrm{C}^{(6)}$. The $\mathrm{pH}\left(\mathrm{H}_{2} \mathrm{O}\right)$ of soils was determined at a soil water ratio of $1: 25$ using a glass electrode $\mathrm{pH}$ meter. The organic carbon content of soils was determined volumetrically by wet oxidation method as described by Jackson ${ }^{(7)}$. Organic matter content was calculated by the Van Bemmelen factor 1.724. The total nitrogen in soils was determined by Kjeldahl's method as described by Jackson(7).

All the soils were poor to very poor in drainage conditions and remained flooded during the monsoon season and also some part of the dry season. The grey color of the soils is related to the gradual removal of a portion of iron from the soil profile by leaching. The formation of various colored mottles is generally associated with seasonal fluctuation of ground water table ${ }^{(8)}$.

*Author for correspondence: <mjuddin66@yahoo.com>. 
Due to alternate wetting and drying conditions abundant quantities of mottles have been formed in all the four soil profiles of the area. The colors of mottles were a combination of yellowish brown to dark brown. The consistence of the surface soils of all the studied profiles was found to be slightly sticky to sticky and slightly plastic to plastic when wet except Ghior series, where it was sticky and plastic when wet. In moist condition, the consistence of top soils is very firm in Arial, while in Amjhupi and Garuri series it is firm. The structure of the soils was massive in all the surface horizons of the soils. Structure was not developed in the surface as this layer had been ploughed for many years. Continuous thick grey to very dark grey cutans along vertical and horizontal ped faces and pores were observed in Arial series, while in Amjhupi series it was broken to moderately thick olive grey cutans along ped and pores. In Garuri and Ghior series coatings were continuous moderately thick dark grey along vertical and horizontal ped faces and pores. The coatings along ped faces were formed by the mechanical down washing of material from the soil surface through the cracks when the soils were flooded and ploughed. Mineral layers were stained blue-grey because of chemical reduction of Iron ${ }^{(9)}$. Many fines to common very fine tubular pores were found in Arial series. Very fine to fine tubular pores were observed in Amjhupi series. In Garuri and Ghior series, many very fine and fine tubular pores were observed. Quantity and distribution of roots in the soil profile depended on the vegetation or crop type and the cultural practices of the soils.

The physical parameters of soils are important criteria in the land use and in land management as well. The soil texture ranged from silty clay to silt loam in the Amjhupi series, silty clay to clay in both the Garuri series and Ghior series, whereas it was clay in the Arial soil series (Table 1). Silty clay and clay texture of the studied soils indicated that these are highly suitable for agriculture especially for rice cultivation under waterlogged condition. The variation in clay, silt and sand content in most profiles suggests that texture is mainly due to sedimentary variations rather than a result of soil forming processes. Silty loam to silty clay and clays are the predominant texture of the studied soil area. The mean sand, silt and clay contents in the studied soils were 5, 35 and 60 percent, respectively. The sand content was much lower in these soils (average 5\%). This is the common feature in the Ganges floodplain soils of Bangladesh ${ }^{(10)}$. Clay is by far the dominant size fraction in the studied soils and therefore, plays a significant role in moulding the physical properties of those soils. Silt is the dominant size fraction in the Amjhupi soil series. The clay content in the studied soil series were more or less higher in the surface and sub surface horizons and then decreased irregularly except Garuri where it increased with depth. The hygroscopic moisture content in the soils ranged from 8 to 3 per cent (Table 1). The mean value of hygroscopic moisture in the soils was 4.77 per cent. Higher moisture percentages were recorded in Ghior (6.1 to 8.0) series which contained higher percentage of clay. The Garuri series also contained higher moisture 
(5.1 to 6.2\%) while Arial and Amjhupi series contained low soil moisture. Such a variation in moisture contents in these two soils may possibly be due to the variation in their clay and organic matter contents.

Table 1. Physical characteristics of the soils.

\begin{tabular}{|c|c|c|c|c|c|c|c|}
\hline \multirow{2}{*}{ Series } & \multirow{2}{*}{ Horizon } & \multirow{2}{*}{$\begin{array}{c}\text { Depth } \\
(\mathrm{cm})\end{array}$} & \multicolumn{3}{|c|}{ Particle size distribution (\%) } & \multirow{2}{*}{$\begin{array}{l}\text { Textural } \\
\text { class }\end{array}$} & \multirow{2}{*}{$\begin{array}{l}\text { Hygroscopic } \\
\text { moisture (\%) }\end{array}$} \\
\hline & & & Sand & Silt & Clay & & \\
\hline \multirow{5}{*}{ Arial } & Apg & $0-20$ & 3 & 27 & 70 & Clay & 3.7 \\
\hline & B2 & $20-60$ & 4 & 23 & 73 & Clay & 3.3 \\
\hline & B3 & $60-100$ & 2 & 31 & 67 & Clay & 3.2 \\
\hline & IIC & $100+$ & 8 & 27 & 65 & Clay & 3.6 \\
\hline & Mean & & 4 & 27 & 69 & & 3.45 \\
\hline \multirow{5}{*}{ Amjhupi } & Ap1 & $0-10$ & 3 & 46 & 51 & Silty clay & 3.4 \\
\hline & Ap2 & $10-15$ & 8 & 40 & 52 & Silty clay & 3.1 \\
\hline & Bt1 & $15-29$ & 4 & 59 & 37 & Silty clay loam & 3.3 \\
\hline & Bt2 & $29-48$ & 6 & 59 & 35 & Silty clay loam & 3 \\
\hline & $\mathrm{C} 1$ & $57-82$ & 25 & 53 & 22 & Silt loam & 3.2 \\
\hline \multirow{7}{*}{ Garuri } & Mean & & 9 & 51 & 39 & & 3.2 \\
\hline & Ap1 & $0-11$ & 1 & 43 & 56 & Silty clay & 5.2 \\
\hline & Ap2 & $11-17$ & 1 & 33 & 67 & Clay & 6.2 \\
\hline & Bt1 & $17-30$ & 2 & 43 & 55 & Silty clay & 5.1 \\
\hline & Bt2 & $30-54$ & 3 & 45 & 52 & Silty clay & 5.7 \\
\hline & Bt3 & $54-90$ & 4 & 40 & 56 & Silty clay & 5.2 \\
\hline & $\mathrm{C} 1$ & $90+$ & 3 & 31 & 66 & Clay & 6.1 \\
\hline \multirow{10}{*}{ Ghior } & Mean & & 2 & 39 & 59 & & 5.58 \\
\hline & Ap1 & $0-12$ & 5 & 22 & 73 & Clay & 7.1 \\
\hline & Ap2 & $12-18$ & 1 & 24 & 75 & Clay & 7.5 \\
\hline & Bt1 & $18-35$ & 1 & 21 & 78 & Clay & 8 \\
\hline & B2 & $35-61$ & 3 & 26 & 71 & Clay & 6.5 \\
\hline & Bt3 & $61-82$ & 3 & 22 & 75 & Clay & 6.3 \\
\hline & Bt4 & $82-103$ & 2 & 27 & 71 & Clay & 6.4 \\
\hline & $\mathrm{C} 1$ & $103+$ & 3 & 46 & 51 & Silty clay & 6.1 \\
\hline & \multirow{2}{*}{\multicolumn{2}{|c|}{$\begin{array}{l}\text { Mean } \\
\text { Grand mean }\end{array}$}} & 3 & 27 & 71 & & 6.84 \\
\hline & & & 5 & 35 & 60 & & 4.77 \\
\hline
\end{tabular}

The percentage of organic matter ranged from 0.18 to $2.41 \%$ with a mean value of $1.18 \%$ (Table 2). The Arial soil contained relatively higher amount of organic matter throughout the profile (2.01 to $2.19 \%$ ). All the soil profiles contained higher amount of organic matter in the surface than in the subsoil with the exception of Arial soil series (Table 2) because in the $\mathrm{C}$ horizon, some buried layers formed there. The total nitrogen contents in the Ganges Floodplain soils from Bangladesh ranged from 0.02 to 0.16 per cent with a mean of 0.08 (Table 2). The highest mean value of nitrogen content among the profiles was found in the Arial soil whereas the lowest amount was found in both 
Amjhupi and Garuri soil. The $\mathrm{C} / \mathrm{N}$ ratio in the studied soils ranged from 6 to 12 with a mean ratio of 10 (Table 2). This indicates that the organic matter fraction was well oxidized even if these soils remain flooded for 3 to 4 months or more every year; in other words, the microbial activity in these soils appear to be quite vigorous.

Table 2. Chemical characteristics of the soils.

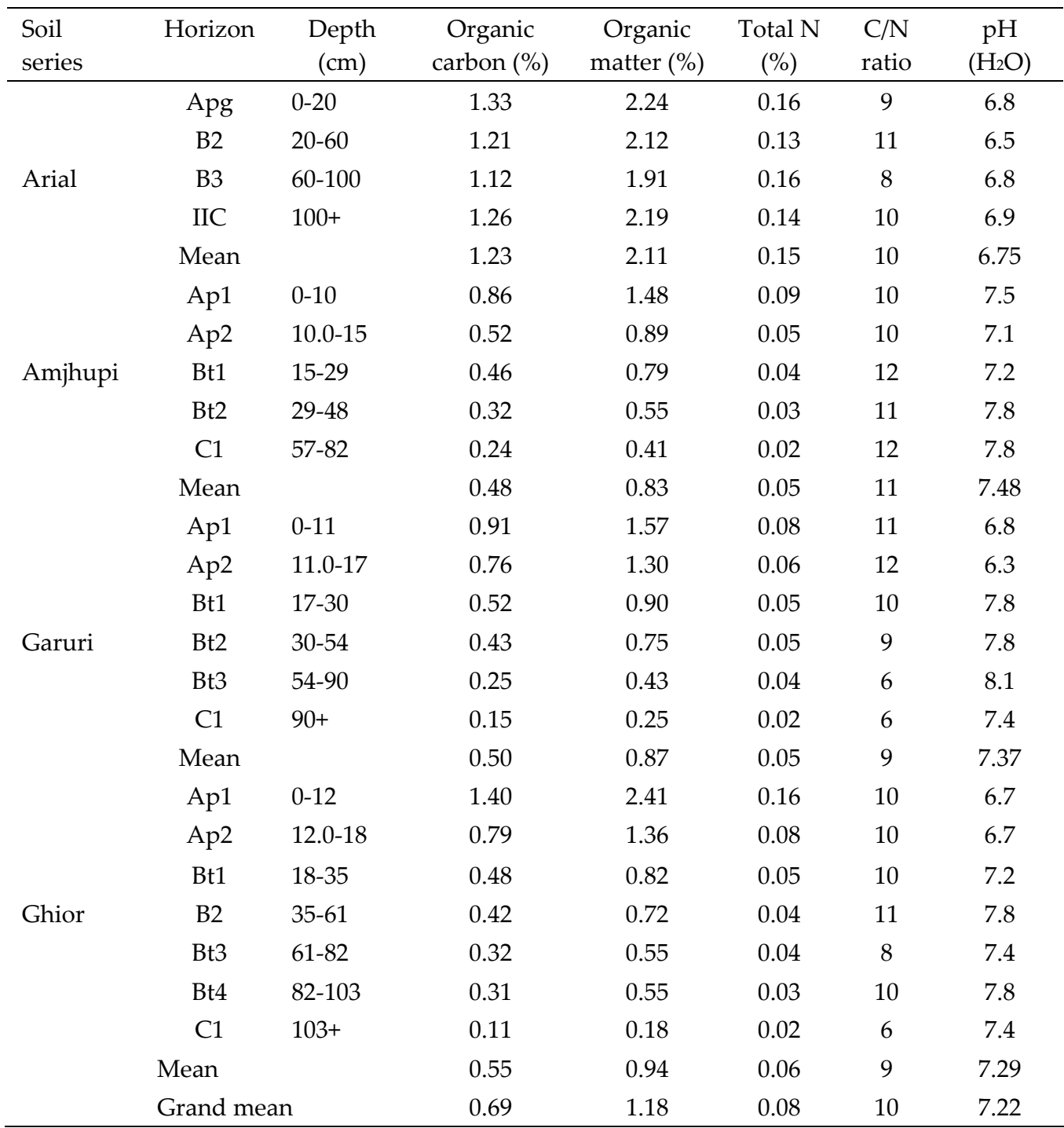

The morphological, physical, chemical and physico-chemical properties of these soils clearly indicate that the soils are of alluvial origin. All the soils under investigation appear to be incompletely developed which means that these are still immature. The soils 
are presently used for rice cultivation during the dry season by irrigation with ground water. These soils therefore remain in waterlogged condition for most of the time of the year. The properties of the top soil are often altered by mechanical manipulation during cultivation when wet. As a result, structure formation in the surface soil has been disturbed constantly.

\section{References}

1. Khan FH 1991. Geology of Bangladesh. University Press Ltd., Dhaka, Bangladesh.

2. Hussain MS, SF Elahi, SM Saheed, MM Hasan, MA Muzib and MM Huq 2005. Benchmark soils of Bangladesh. Land quality assessment project. Department of Soil, Water and Environment, University of Dhaka. Dhaka-1000. Bangladesh.

3. Soil Survey Staff 1998. Key to Soil Taxonomy. $7^{\text {th }}$ ed. Soil Conservation Service, USDA, Washington, D. C.

4. Soil Survey Staff 1991. Soil Survey Manual. USDA Handbook No. 18. US Govt. Printing Office, Washington, D.C.

5. Day PR 1965. Particle formation and particle-size analysis. In: Methods of Soil Analysis (eds. C. A. Black et. al.). American Society of Agronomy, Madison, Wisconsin, p. 545-667.

6. Black CA 1965. Methods of soil Analysis. Part 1 and 2. Am. Soc. Agron.; Madison, Wisconsin.

7. Jackson ML 1967. Soil Chemical Analysis. Prentice Hall of India Pvt. Ltd., New Delhi. p. 25-39.

8. Makeague JA 1965. Relationship of water table and Eh to properties of three clay soils in the Ottawa Vally. Can. J. Soil Sci. 45: 49-62.

9. Pidwirny M 2006. Soil Pedogenesis. Fundamentals of Physical Geography, $2^{\text {nd }}$ Ed., Central Michigan, USA.

10. FAO, 1971. Bangladesh: Soil Resources. Soil Survey Project of Technical Report 3. Food and Agriculture Organization of the United Nations, Rome.

(Manuscript received on 22 January, 2012; revised on 23 May, 2012) 